\title{
Genetic Variability, Heritability and Genetic Advance Studies in Blackgram [Vigna mungo (L.) Hepper] Across Seasons
}

\author{
Sidramappa ${ }^{*}$, P. H. Kuchanur, M. Shobharani, B. Arunkumar, \\ S. A. Kulkarni, H. C. Sowmya, D. Sheela, Laxuman and S. Bharati \\ University of Agricultural Sciences, Raichur-585401, Karnataka, India \\ *Corresponding author
}

\section{A B S T R A C T}

\begin{tabular}{l} 
Ke y w or d s \\
Blackgram, \\
variability, GCV, \\
PCV, Heritability, \\
GA, GAM \\
\hline Article Info \\
$\begin{array}{l}\text { Accepted: } \\
\text { 10 September } 2020 \\
\text { Available Online: } \\
\text { 10 October } 2020\end{array}$ \\
\hline
\end{tabular}

\section{Introduction}

Among pulses, blackgram (Vigna mungo (L.) is an important short duration crop widely cultivated in India. It is an excellent source of easily digestible good quality protein and also has ability to restore the soil fertility through symbiotic nitrogen fixation like any other leguminous crop. It is cultivated in almost all parts of India and is third most important pulse crop both in acreage and production. However, it is mainly grown in the states of Madhya Pradesh, Maharashtra, Uttar Pradesh,
Rajasthan, Karnataka and Bihar. During the post green revolution period, the production of pulses recorded a negative growth rate and which adversely affected the per capita availability of pulses which has declined from $60.7 \mathrm{~g}$ per day in 1950 to $43.0 \mathrm{~g}$ in 2016 (Anon., 2017).

This situation is due to very slow progress in the improvement of productivity of all pulses and also stagnation in pulse growing area. Lack of genetic variability is considered as one of the major constraints in achieving 
higher productivity in many pulses including blackgram. To overcome stagnation in pulse growing area, we need to introduce crop to the new areas and seasons for cultivation (in Tungabhadra and Upper Krishna project command areas during summer after harvesting paddy, pigeonpea and Bt cotton).

We need make systematic studies to characterise existing variability for yield and its component traits across the seasons for selection of genotypes suitable for kharif as well as summer. In view of the above, the present study was conducted with the objective of assessing the genetic variability, heritability, genetic advance for yield and yield components among 25 blackgram genotypes evaluated across kharif and summer seasons.

\section{Materials and Methods}

The experiment material for the present investigation consisted of 25 blackgram genotypes representing different sources of origin (Agricultural Research Station, Bidar; Nuclear Agriculture and Biotechnology Division, Bhabha Atomic Research Centre, Trombay, Mumbai; Indian Institute of Pulse research, regional station, Dharwad and Regional Agricultural Research Station, LAM, Guntur).

They were evaluated during kharif-2018 and summer-2019 across three locations viz., Agricultural Research Station, Bidar, Agricultural Research Station, Kalaburagi and Agricultural Research Station, Bheemarayanagudi.

The experimental trial was laid out in Randomized Block Design with two replications. Each genotype in each replication was represented by a plot size of 4 rows of 4 meter length with a spacing of 30 $\mathrm{cm}$ between rows and $10 \mathrm{~cm}$ between plants within a row. All the recommended agronomic practices were followed to raise a good crop. Observations on 10 quantitative traits were recorded. Observations on plant height, branches per plant, clusters per plant, pods per plant, seeds per pod, pod length and100-seed weight were recorded on five competitive plants selected at random per genotype in each replication. Whereas, observations on days to 50 per cent flowering, days to maturity and seed yield (kg/plot) were recorded on plot basis. The seed yield per plot was recorded and weighed in kilograms $(\mathrm{kg})$ and converted into seed yield $\mathrm{kg} / \mathrm{ha}$ for each of the genotype.

The data obtained over six environments were subjected to pooled analysis. Statistical analysis was carried out using WINDOSTAT 8.5 software and genotypic coefficient of variation (GCV), phenotypic coefficient variation (PCV), heritability in broad sense $\left(h^{2}\right)$, genetic advance (GA), genetic advance as percentage of mean (GAM) were estimated.

\section{Results and Discussion}

\section{Analysis of variance (ANOVA)}

The pooled analysis of variance showed significant differences among the genotypes evaluated for all traits except for pod length and number of seeds per pod (Table 1) indicating the presence of variability among the genotypes for various traits and indicating the possibility genetic improvement through selection.

High variability present in the breeding material would increase the probability of producing desirable recombinants in successive generations. Similarly, Senapati and Misra (2010) and Kumar et al., (2015) recorded wide range of variation for all the quantitative characters in blackgram. 
Table.1 Pooled analysis of variance (ANOVA) for 10 quantitative traits in 25 genotypes of blackgram

\begin{tabular}{|c|c|c|c|c|c|c|c|c|c|c|c|}
\hline Source of Variations & df & $\begin{array}{c}\text { Days to } \\
50 \% \\
\text { flowering }\end{array}$ & $\begin{array}{l}\text { Days to } \\
\text { maturity }\end{array}$ & $\begin{array}{c}\text { Plant } \\
\text { height } \\
\text { (cm) }\end{array}$ & $\begin{array}{c}\text { Number of } \\
\text { branches } \\
\text { per plant }\end{array}$ & $\begin{array}{c}\text { Number of } \\
\text { pods per } \\
\text { plant }\end{array}$ & $\begin{array}{c}\text { Number of } \\
\text { clusters } \\
\text { per plant }\end{array}$ & $\begin{array}{l}\text { Number } \\
\text { of seeds } \\
\text { per pod }\end{array}$ & $\begin{array}{c}\text { Pod } \\
\text { length } \\
(\mathrm{cm})\end{array}$ & $\begin{array}{c}100-\text { seed } \\
\text { weight }(\mathrm{g})\end{array}$ & $\begin{array}{l}\text { Seed yield } \\
\text { (kg/ha) }\end{array}$ \\
\hline Varieties & 24 & $3.38 * *$ & $15.73 * *$ & $44.69 * *$ & $0.46 * *$ & $48.38 * *$ & $2.07 *$ & 0.18 & 0.07 & $0.67 * *$ & $5.23 * *$ \\
\hline Environments & 5 & $24.12 * *$ & $121.01 * *$ & $242.35^{* *}$ & $27.46 * *$ & $322.08 * *$ & $84.36 * *$ & $11.71 * *$ & $2.89 * *$ & $2.40 * *$ & $103.53 * *$ \\
\hline Env.+ (Var. x Env.) & 125 & $2.76 * *$ & $12.60 * *$ & $30.77 *$ & $1.31 * *$ & $25.44 * *$ & $4.39 * *$ & $0.59 * *$ & $0.19 * *$ & $0.17 * *$ & $5.83 * *$ \\
\hline Pooled Error & 144 & 0.00 & 0.00 & 3.28 & 0.09 & 2.60 & 0.16 & 0.09 & 0.03 & 0.01 & 0.31 \\
\hline
\end{tabular}

* Significant at $5 \%$ probability ** Significant at $1 \%$ probability

Table.2 Genetic variability parameters (pooled over six environments) for 10 quantitative traits in blackgram genotypes

\begin{tabular}{|c|c|c|c|c|c|c|c|c|c|c|}
\hline $\begin{array}{c}\text { Genetic } \\
\text { parameters/ } \\
\text { Characters }\end{array}$ & $\begin{array}{c}\text { Days to } \\
50 \% \\
\text { flowering }\end{array}$ & $\begin{array}{l}\text { Days to } \\
\text { maturity }\end{array}$ & $\begin{array}{c}\text { Plant } \\
\text { height } \\
(\mathbf{c m})\end{array}$ & $\begin{array}{c}\text { Number of } \\
\text { branches } \\
\text { per plant }\end{array}$ & $\begin{array}{c}\text { Number } \\
\text { of pods } \\
\text { per plant }\end{array}$ & $\begin{array}{l}\text { Number of } \\
\text { clusters } \\
\text { per plant }\end{array}$ & $\begin{array}{l}\text { Number } \\
\text { of seeds } \\
\text { per pod }\end{array}$ & $\begin{array}{c}\text { Pod } \\
\text { length } \\
(\mathbf{c m})\end{array}$ & $\begin{array}{c}100- \\
\text { seed } \\
\text { weight }\end{array}$ & $\begin{array}{c}\text { Seed } \\
\text { yield } \\
\text { (kg/ha) }\end{array}$ \\
\hline Mean & 38.83 & 73.86 & 33.56 & 3.18 & 22.04 & 5.81 & 5.80 & 4.21 & 4.59 & 861.20 \\
\hline PCV & 3.76 & 4.14 & 16.05 & 18.84 & 21.07 & 20.23 & 8.18 & 7.70 & 8.42 & 18.86 \\
\hline GCV & 3.26 & 3.81 & 12.98 & 13.56 & 14.86 & 16.61 & 5.88 & 4.34 & 5.82 & 14.79 \\
\hline$h^{2}($ Broad Sense $)$ & 75.23 & 84.70 & 65.36 & 51.85 & 49.75 & 67.40 & 51.53 & 31.83 & 47.72 & 61.44 \\
\hline GA & 1.87 & 3.05 & 3.13 & 0.83 & 2.21 & 1.51 & 0.73 & 0.37 & 0.61 & 1.61 \\
\hline GAM & 4.82 & 4.13 & 9.31 & 25.98 & 10.02 & 25.90 & 12.61 & 8.86 & 13.32 & 18.70 \\
\hline
\end{tabular}




\section{Estimates of genetic parameters}

The result showed that phenotypic coefficient of variation (PCV) was relatively higher than genotypic coefficient of variation (GCV) indicating that the influence of environment on phenotypic expression of each trait. But the difference between genotypic and phenotypic coefficient of variation was very little for days to 50 per cent flowering and days to maturity signifying very little influence of environment in expression of the these traits. The high variability (phenotypic and genotypic coefficients of variation) was observed for number of pods per plant (21.07 and 14.86) followed by number of clusters per plant (20.23 and 16.61), seed yield (18.86 and 14.79) and number of branches per plant (18.84 and 13.56). Earlier workers also reported more variation for these characters; Sirohi et al., (1994) for plant height and seed yield; Neelavathi and Govidarasu (2010) for clusters per plant and seed yield; Kuralasan et al., (2018) for number of branches, number of clusters and seed yield per plant. According to Sivasubramanian and Menon (1973) GCV and PCV more than $20 \%$ considered as high, whereas, values less than $10 \%$ are considered to be low and values between $10 \%$ and $20 \%$ being considered to be moderate. Seed yield and its important component traits showed high to intermediate GCV and PCV (Table 2). This indicated that these traits could be improved for breeding high yielding varieties through selection and hybridization.

The broad sense heritability for the traits under study ranged from $31.83 \%$ to $84.70 \%$ (Table 2). According to Robinson et al., (1949), broad sense heritability was classified as low ( $<30 \%)$, medium (30\% to $60 \%$ ) and high $(>60 \%)$. High heritability was observed for days to 50 per cent flowering, days to maturity, plant height, number clusters per plant and seed yield indicating that these traits could be easily improved through selection.
Byregouda et al., (1997), Reena et al., (2016) and Mohanlal et al., (2018) also reported high heritability for these traits. The traits showing moderate heritability viz., number branches per plant, pods per plant and could be improved through indirect selections.

Since heritability does not always indicate genetic gain, heritability coupled with genetic advance is more effective for selection (Johnson et al., 1955). Genetic advance indicates the expected progress as the result of selection. It used to estimate the type of gene action in polygenetic traits. Genetic advance as per cent of mean classified as low $(<10 \%)$, moderate (10\%-20\%) and high (>20\%). In this study, it ranged from 4.13 for days to maturity to $25.98 \%$ for number of branches for plant. High heritability coupled with high genetic advance was exhibited by seed yield and number of branches per plant indicating that these traits could be easily be selected through phenotypic selection irrespective of the season. Similar results were also reported by Mohanlal et al., (2018) and Kuralarasan et al., (2018). The overall result showed the presence of adequate variability in the genotypes for number of pods per plant, number of clusters per plant, number of branches per plant and seed yield. This variation could be effectively utilised using appropriate breeding techniques to develop improved varieties.

\section{References}

Byregowda, M., Chandraprakash, J. and Shantala, J., 1997, Estimates of genetic variability and heritability in blackgram (Vigna mungo L.). Crop Res. 13: 369-372.

Johnson, H. W., Robinson, H. F. and Comstock, R. E., 1955, Genotypic and phenotypic correlation in soybean and their implications in selection. Agron. J. 47: 477-483. 
Kumar, V. G., Vanaja, M., Abrahum, B., Anitha, Y., Lakshmi, N. J. and Maheswari, M., 2015, Variability, heritability and genetic advance for quantitative traits in blackgram (Vigna mungo (L.) Hepper). Int. J. Curr. Sci., 17: $37-42$

Kuralarasan, V., Vanniarajan, C., Kanchana, S., Veni, K. and Lavanya S. A., 2018, Genetic divergence, heritability and genetic advance in mutant lines of urdbean [Vigna mungo (L.) Hepper]. Legume Res. 41(6): 833-836.

Mohanlal, V. A., Saravanan, K.T., Sabesan., 2018, studies on genetic correlation and path coefficient analysis of blackgram (Vigna mungo [L.] hepper) genotypes under salinity. J. Phytol. 10: 9-11.

Neelavathi, S. and Govindarasu, R., 2010, Analysis of variability and diversity in rice fallow blackgram [Vigna mungo (L.) Hepper]. Legume Res. 33 (3): 206-210.
Reena, M., Tikle, A. N., Ashok, S., Ashok, M., Rekhakhandia. and Mahipal, S., 2016, Correlation, path-coefficient and genetic diversity in blackgram [Vigina mungo (L) Hepper]. Int. Res. J. Plant. 7 (1): 1-11.

Robinson, H. F., Comstock, R. E. and Harvey, P. H., 1949, Genotypic and phenotypic correlations in corn and their implications in selection. Agron. J., 43: 282-287

Senapati, N. and Misra, R. C., 2010, Genetic divergence and variability studies among micromutants in blackgram [Vigna mungo (L.) Hepper]. Legume Res., 33 (2): 108 - 113.

Sirohi, A., Kalia, V., Verma, S. and Rahee, V. K., 1994, Variability studies in blackgram. Crop Res., 7: 494-497.

Sivasubramanian, S. and Menon, M., 1973, Heterosis and inbreeding depression in rice. Madras Agric. J., 60: 1139.

\section{How to cite this article:}

Sidramappa, P. H. Kuchanur, M. Shobharani, B. Arunkumar, S. A. Kulkarni, H. C. Sowmya, D. Sheela, Laxuman and Bharati, S. 2020. Genetic Variability, Heritability and Genetic Advance Studies in Blackgram [Vigna mungo (L.) Hepper] Across Seasons. Int.J.Curr.Microbiol.App.Sci. 9(10): 879-883. doi: https://doi.org/10.20546/ijcmas.2020.910.105 